\title{
HIGH RESOLUTION LC-MS/MS SCREENING FOR SECONDARY METABOLITES IN BULGARIAN SPECIES OF GENUS Astragalus L.
}

\author{
Aleksandar M. Shkondrov ${ }^{\mathrm{a}}$ and Ilina N. Krasteva ${ }^{\mathrm{a}, *,(1)}$ \\ a Department of Pharmacognosy, Faculty of Pharmacy, Medical University of Sofia, Sofia, Bulgaria
}

Recebido em 01/09/2020; aceito em 08/02/2021; publicado na web em 26/02/2021

\begin{abstract}
The phytochemical content of some Astragalus species distributed in Bulgarian flora has been previously studied. Among other compounds, flavoalkaloids, acylated flavonoids, flavonoid triglycosides and cycloartane saponins have been isolated so far. The composition of the rest of the representatives of this genus in Bulgaria is not explored yet. The aim of this study was to perform a screening for the presence of selected rare secondary metabolites (flavoalkaloids, acylated flavonoids, flavonoid triglycosides and cycloartane saponins) in selected Astragalus species. Samples were collected in different phenological stages and from different locations in the country. A novel and rapid ultra-high performance liquid chromatography - high resolution electrospray ionisation mass spectrometry (UHPLC-HRESIMS) method was developed and applied. For the first time a flavoalkaloid glycoside was determined from extracts of A. onobrychis var. chlorocarpus and A. glycyphylloides. From A. depressus an acylated derivative of kaempferol was newly identified. The flavonol triglycosides camelliaside A, alcesefoliside and mauritianin were proved in samples of A. glycyphylloides, A. onobrychis var. chlorocarpus and A. cicer for the first time as well.
\end{abstract}

Keywords: Astragalus species; flavoalkaloids; flavonoids; saponins; qualitative analysis; UHPLC-HRESIMS.

\section{INTRODUCTION}

Genus Astragalus L. (Fabaceae) is comprised of more than 3500 species, distributed in every continent except Antarctica. ${ }^{1}$ In Europe the genus is presented with 135 species, 31 of which are distributed in Bulgaria. ${ }^{2,3}$ The plants have been known to accumulate mainly three groups of pharmacologically active compounds - polysaccharides, flavonoids and saponins. ${ }^{4}$

Recently, $N$-(8-methylquercetin-3- $O$-[ $\alpha$-L-rhamnopyranosyl$(1 \rightarrow 2)$-[ $\alpha$-L-rhamnopyranosyl- $(1 \rightarrow 6)]-\beta$-D-galactopyranosyl] $)$ 3-hydroxypiperidin-2-one and $N$-(8-methylkaempferol-3- $O$-[ $\alpha$-Lrhamnopyranosyl- $(1 \rightarrow 2)$-[ $\alpha$-L-rhamnopyranosyl- $(1 \rightarrow 6)]-\beta-D-$ galactopyranosyl])-3-hydroxypiperidin-2-one were isolated from A. monspessulanus subsp. monspessulanus. ${ }^{5}$ Flavoalkaloids are a rare group of plant secondary metabolites, known previously only as aglycones. ${ }^{6}$ This leads to a further investigation of possible accumulation of flavoalkaloids in other representatives of the genus.

Long considered a chemotaxonomical marker of genera Rosa and Plathyrodon (Rosaceae), flavonoids acylated with 3-hydroxy3-methylglutaric acid were also isolated from Astragalus species. ${ }^{7-9}$ Quercetin-3- $O$ - $\alpha$-L-rhamnopyranosyl-( $1 \rightarrow 2)$-[6- $O$-(3-hydroxy-3methylglutaryl)- $\beta$-D-galactopyranoside and kaempferol-3- $O-\alpha-\mathrm{L}-$ rhamnopyranosyl-( $1 \rightarrow 2)$-[6- $O$-(3-hydroxy-3-methylglutaryl)- $\beta$-Dgalactopyranoside were obtained from the overground parts of $A$. monspessulanus subsp. illyricus. ${ }^{5}$ This presents a new opportunity to establish the chemotaxonomical significance of these acylated flavonoids for the genus.

Flavonoid triglycosides occur quite rarely and their biosynthesis is undoubtedly a result of interconnecting pathways. ${ }^{10}$ Quercetin3-O- $\alpha$-L-rhamnopyranosyl- $(1 \rightarrow 2)$-[ $\alpha$-L-rhamnopyranosyl$(1 \rightarrow 6)]-\beta$-D-galactopyranoside (alcesefoliside) and kaempferol3-O- $\alpha$-L-rhamnopyranosyl- $(1 \rightarrow 2)$ - $[\alpha$-L-rhamnopyranosyl$(1 \rightarrow 6)]-\beta$-D-galactopyranoside (mauritianin) were isolated from the aerial parts of A. monspesulanus subsp. monspesulanus. ${ }^{5}$

*e-mail: krasteva.ilina@abv.bg
Kaempferol-3-O-[2-O- $\beta$-D-galactopyranosyl-6- $O-\alpha-\mathrm{L}-$ rhamnopyranosyl]- $\beta$-D-glucopyranoside (camelliaside A) was isolated from the herbs of A. glycyphyllos. ${ }^{11}$

Studies of Bulgarian Astragalus species showed that they have an intermediate content - some contain pentacyclic triterpenoid saponins, while in other species the accumulation of cycloartane saponins was proved. ${ }^{12,13}$ Previously, $17(R), 20(R)-3 \beta, 6 \alpha, 16 \beta-$ trihydroxycycloartanyl-23-carboxilic acid 16-lactone $3-O-\beta-\mathrm{D}-$ glucopyranoside was isolated from the herbs of A. glycyphyllos. ${ }^{11}$ From a taxonomical point of view the saponin content of other species is of particular interest. ${ }^{14}$

The aim of this study was to conduct an UHPLC-HRESIMS screening for the presence of selected rare secondary metabolites in species of genus Astragalus occurring in Bulgaria

\section{EXPERIMENTAL}

\section{Plant material}

The overground parts of seven Astragalus species (Table 1) were collected either in flowering or in fructification, from marked plants and/or from different localities in Bulgaria. The species were identified by Dr. D. Pavlova from Faculty of Biology, Sofia University, Bulgaria and two of us (A. S. and I. K.). Voucher specimens were deposited in the Herbarium of the Sofia University (SO) or at the Herbarium of the Institute of Biodiversity and Ecosystem Research at the Bulgarian Academy of Sciences (SOM).

\section{Extraction}

Overground parts were dried at room temperature and then individually reduced to a powder. A sample of each $(200 \mathrm{mg})$ was refluxed twice with $3 \mathrm{~mL} 80 \% \mathrm{MeOH}$ on a boiling water bath $\left(100{ }^{\circ} \mathrm{C}\right)$ for $30 \mathrm{~min}$ each. The extracts obtained were filtered, combined in a volumetric flask and the volume adjusted to $10.0 \mathrm{~mL}$ with the same solvent. An aliquot of $2 \mu \mathrm{L}$ was injected to UHPLC. 
Table 1. Samples of Bulgarian Astragalus species

\begin{tabular}{|c|c|c|c|c|c|}
\hline Sample No. & Overground parts of & Year & Locality; coordinates & Voucher specimen & Phenological stage \\
\hline 1 & A. cicer & 2013 & Sofia; $42^{\circ} 41^{\prime} 52^{\prime \prime} \mathrm{N}, 23^{\circ} 19^{\prime} 19^{\prime \prime} \mathrm{E}$ & SO 102681 & flowering \\
\hline 2 & A. cicer & 2016 & Sofia; $42^{\circ} 41^{\prime} 52^{\prime \prime} \mathrm{N}, 23^{\circ} 19^{\prime} 19^{\prime \prime} \mathrm{E}$ & SOM 1394 & fructification \\
\hline 3 & A. depressus & 2015 & Erma; $42^{\circ} 48^{\prime} 45^{\prime \prime} \mathrm{N}, 22^{\circ} 34^{\prime} 52^{\prime \prime} \mathrm{E}$ & SOM 1402 & flowering \\
\hline 4 & A. glycyphylloides & 2018 & Vitosha; $42^{\circ} 33^{\prime} 36^{\prime \prime} \mathrm{N}, 23^{\circ} 16^{\prime} 48^{\prime \prime} \mathrm{E}$ & SO 093817 & flowering \\
\hline 5 & A. glycyphyllos & 2019 & Rila; 427'40”N, 237’56”E & SO 107612 & flowering \\
\hline 6 & A. glycyphyllos & 2012 & Vitosha; $42^{\circ} 33^{\prime} 36^{\prime \prime} \mathrm{N}, 23^{\circ} 16^{\prime} 48^{\prime \prime} \mathrm{E}$ & SO 107613 & flowering \\
\hline 7 & A. monspessulanus subsp. monspessulanus & 2016 & Devin; $41^{\circ} 43^{\prime} 41^{\prime \prime} \mathrm{N}, 24^{\circ} 26^{\prime} 59^{\prime \prime} \mathrm{E}$ & SOM 1391 & fructification \\
\hline 8 & A. monspessulanus subsp. monspessulanus & 2016 & Slavianka; $41^{\circ} 33^{\prime} 57^{\prime \prime} \mathrm{N}, 24^{\circ} 44^{\prime} 41^{\prime \prime} \mathrm{E}$ & SOM 1392 & flowering \\
\hline 9 & A. monspessulanus subsp. illyricus & 2015 & Erma; $42^{\circ} 48^{\prime} 45^{\prime}{ }^{\prime}, 2^{\circ} 34^{\prime} 52^{\prime \prime} \mathrm{E}$ & SO 107532 & flowering \\
\hline 10 & A. onobrychis var. chlorocarpus & 2013 & 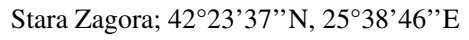 & SO 107538 & flowering \\
\hline 11 & A. onobrychis var. chlorocarpus & 2016 & Golo Bardo; 42³5’ 17’’N, 233’2’E & SOM 1393 & flowering \\
\hline 12 & A. onobrychis var. chlorocarpus & 2016 & Vitosha; $42^{\circ} 33^{\prime} 36^{\prime \prime} \mathrm{N}, 23^{\circ} 16^{\prime} 48^{\prime \prime} \mathrm{E}$ & SOM 1390 & flowering \\
\hline 13 & A.ponticus & 2013 & Pleven; 4324'32”N, 2437'4'”E & SO 107539 & flowering \\
\hline
\end{tabular}

Ultra high performance liquid chromatography-high resolution electrospray ionization mass spectrometry (UHPLCHRESIMS)

A Q Exactive ${ }^{\mathrm{TM}}$ Plus Orbitrap mass spectrometer with a heated electrospray ionisation (HESI) ion source (ThermoFisher Scientific, Bremen, Germany) coupled with a UHPLC system (Dionex UltiMate 3000 RSLC, ThermoFisher Scientific, Bremen, Germany) was used. The full scan MS was set at: resolution 70000 (at $\mathrm{m} / \mathrm{z}, 200)$, AGC target $3 \mathrm{e}^{6}$, max IT $100 \mathrm{~ms}$, scan range 250 to $1700 \mathrm{~m} / z$. The $\mathrm{MS}^{2}$ conditions were: resolution 17500 (at $\mathrm{m} / \mathrm{z}, 200$ ), AGC target $1 \mathrm{e}^{5}$, max IT $50 \mathrm{~ms}$, mass range $\mathrm{m} / \mathrm{z} 200$ to 2000 , isolation window $2.0 \mathrm{~m} / \mathrm{z}$, and (N)CE 20. The ionization device (HESI source) was operating at: +3.5 or $-2.5 \mathrm{kV}$ spray voltage and $320{ }^{\circ} \mathrm{C}$ capillary and probe temperature, 38 arbitrary units (a.u., as set by the Extactive Tune software) of sheath gas and 12 a.u. of auxiliary gas (both Nitrogen); S-Lens RF level 50.0. UHPLC separations were performed using a Kromasil ${ }^{\odot} \mathrm{C}_{18}$ column $(1.9 \mu \mathrm{m}, 2.1$ x $50 \mathrm{~mm}$, Akzo Nobel, Sweden) maintained at $40{ }^{\circ} \mathrm{C}$; mobile phase $\mathrm{H}_{2} \mathrm{O}$ added $0.1 \% \mathrm{HCOOH}(\mathrm{A})$ and $\mathrm{MeCN}$ added $0.1 \% \mathrm{HCOOH}(\mathrm{B})$ with a flow rate of $0.3 \mathrm{~mL} /$ min and gradient elution (10\% B for $0.5 \mathrm{~min}$, then increase to $30 \%$ B for 7 min, isocratic with $30 \%$ B for $1.5 \mathrm{~min}$, increase to $95 \%$ B for $3.5 \mathrm{~min}$, isocratic with $95 \% \mathrm{~B}$ for $2 \mathrm{~min}$, then return to $10 \% \mathrm{~B}$ for $0.1 \mathrm{~min}$ ).

\section{Reference substances}

The structures of the reference substances are shown in Figure 1 and the chemical names are given in Table 2. They were isolated from the plant source (purity more than $99 \%$, HPLC) and their structures were confirmed by extensive spectral analyses and comparison to data reported before..$^{5,11}$ Rutin (99.8\% purity) was purchased from Sigma Aldrich. Standard solutions of each reference substance were prepared in $\mathrm{MeOH}(100 \mathrm{ng} \mathrm{mL})$. Two $\mu \mathrm{L}$ of each solution were injected in the UHPLC-HRESIMS system three times.

\section{Detection}

Detection of the compounds in the samples was based on the full scan chromatograms in both positive and negative mode, considering the retention time, compared to the standards. Identification was supported by $\mathrm{MS}^{2}$ experiments which revealed the aglycone part of the molecule in question as well as the successive loss of monosaccharides of the sugar moiety. The fragmentation pattern was compared to that of the reference substance (Table 2). The following criteria were adopted for the identification: coincidence of both the retention time and of the fragmentation pattern with that of the standard in both positive and negative modes.

\section{Software}

The software Xcalibur ${ }^{\odot}$, Version 4.2 (Thermo Scientific) was used to collect raw data and to process the results.

\section{RESULTS AND DISCUSSION}

\section{Method development}

Liquid chromatography coupled with mass spectrometry is considered to be one of the most accurate methods to identify multiple compounds in complex samples. ${ }^{15}$ A novel UHPLC-HRESIMS method was developed for determination of selected secondary metabolites in plant extracts. The method was rapid and efficient. As recommended by the The International Council for Harmonization of Technical Requirements for Pharmaceuticals for Human Use (ICH) the validation was performed on several parameters. ${ }^{16}$ Specificity against each reference substance was examined on blank solutions. There were no peaks in the chromatogram of the blank solution with retention time (Rt) similar to any of the reference compounds (Table 2). The limit of detection, based on three times the signal-tonoise ratio, was calculated for each reference substance (Table 2) by injecting $2 \mu \mathrm{L}$ of each standard solution three times. The repeatability (SD \%) on six solutions containing rutin was $\pm 1.1 \%$.

Rutin, as a well-known flavonoid was initially used to develop the method. ${ }^{10}$ An ion $[\mathrm{M}-\mathrm{H}]^{-}\left(\mathrm{m} / \mathrm{z}, 609.1470, \mathrm{C}_{27} \mathrm{H}_{29} \mathrm{O}_{16}{ }^{-}\right)$and in $\mathrm{MS}^{2}$ ions with $m / z, 300.0280\left(\mathrm{C}_{15} \mathrm{H}_{8} \mathrm{O}_{7}^{-*}\right.$, [Que-H] $\left.{ }^{*}\right)$ and with $m / z, 301.0349$ $\left(\mathrm{C}_{15} \mathrm{H}_{9} \mathrm{O}_{7}^{-}\right.$, [Que-H] $)$were observed, while in the positive mode a precursor ion $[\mathrm{M}+\mathrm{H}]^{+}$with $m / z, 611.1605\left(\mathrm{C}_{27} \mathrm{H}_{31} \mathrm{O}_{16}{ }^{+}\right)$and in the $\mathrm{MS}^{2}$ a corresponding ion with $m / z 303.0496\left(\mathrm{C}_{15} \mathrm{H}_{11} \mathrm{O}_{7}^{+}\right)$for [Que+H] ${ }^{+}$were registered. ${ }^{10}$ The flavonoid was identified in all extracts except those of A. depressus and A. glycyphylloides (Samples 3 and 4, Table 3). These findings are with accordance with previous results. ${ }^{4,17-19}$ Moreover, the results of rutin content and their coincidence with the literature prove the accuracy of the screening method presented.

\section{Mass spectral analysis of reference substances}

The mass fragmentation of the standards was investigated and the experimental findings are presented in Table 2. The principal fragmentation patterns of flavoalkaloids and flavonoids are shown on Figure 2, except for rutin, since its fragmentation was previously described. ${ }^{10}$ The fragmentation of ECAS is presented in Figure 3. 
<smiles>CCOCCN1CCCC(O)C1=O</smiles><smiles>CC(C)=O</smiles><smiles>C[C@H]1OC(OC[C@H]2O[C@H](C(C)(C)C)[C@H](OC3O[C@H](CO)[C@@H](O)[C@H](O)[C@H]3O)[C@@H](O)[C@H]2O)[C@H](O)[C@@H](O)[C@@H]1O</smiles><smiles>CNCCN1CCCC(O)C1=O</smiles><smiles>C[C@H]1O[C@H](O[C@H]2[C@H](Oc3c(-c4ccc(O)c(O)c4)oc4cc(O)cc(O)c4c3=O)O[C@H](CO[C@H]3O[C@H](C)[C@H](O)[C@@H](O)[C@H]3O)[C@H](O)[C@H]2O)[C@H](O)[C@@H](O)[C@@H]1O</smiles><smiles>C[C@@H]1O[C@H](OC[C@H]2O[C@@H](Oc3c(-c4ccc(O)c(O)c4)oc4cc(O)cc(O)c4c3=O)[C@@H](O)[C@H](O)C2O)[C@H](O)[C@H](O)[C@H]1O</smiles>

Rutin<smiles>CC1O[C@H](O[C@H]2[C@H](Oc3c(-c4ccc(O)cc4)oc4cc(O)cc(O)c4c3=O)O[C@H](COC(=O)CC(C)(O)CC(=O)O)[C@@H](O)[C@H]2O)[C@H](O)[C@H](O)[C@H]1O</smiles>

QueHMG

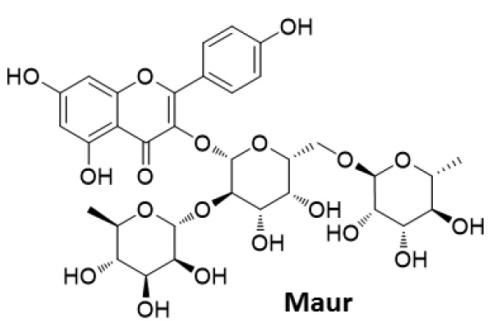<smiles>CCS(=O)(=O)c1ccc(SC)cc1</smiles>

Figure 1. Reference substances used to perform the screening; abbreviations are given in Table 2

In the negative $\mathrm{MS}^{2}$ spectrum of all flavonol glycosides described above, a fragment ion with $\mathrm{m} / z, 151\left(\mathrm{C}_{7} \mathrm{H}_{3} \mathrm{O}_{4}{ }^{-}\right)$and in the positive $\mathrm{MS}^{2}$ spectrum a fragment ion with $\mathrm{m} / z, 153\left(\mathrm{C}_{7} \mathrm{H}_{5} \mathrm{O}_{4}{ }^{+}\right)$, both due to retroDiels-Alder (RDA) fragmentation of their aglycone $\left({ }^{1,3} \mathrm{~A}^{-}\right.$or $\left.{ }^{1,3} \mathrm{~A}^{+}\right)$were observed. ${ }^{20}$ This was not registered for the flavoalkaloids investigated.

In the mass spectrum of QueFA, a deprotonated ion $[\mathrm{M}-\mathrm{H}]^{-} \mathrm{m} / \mathrm{z}$ $882.2692\left(\mathrm{C}_{39} \mathrm{H}_{48} \mathrm{NO}_{22}{ }^{-}\right)$with low abundance was observed. The fragmentation led to an ion with $m / z 315.0505\left(\mathrm{C}_{16} \mathrm{H}_{11} \mathrm{O}_{7}{ }^{-}\right)$, corresponding to deprotonated methylquercetin [methylQue- $\mathrm{H}$ ] after cleavage of the hydroxypiperidine-2-one moiety. ${ }^{21-23}$ A protonated ion $[\mathrm{M}+\mathrm{H}]^{+} \mathrm{m} / \mathrm{z}$ $884.2809\left(\mathrm{C}_{39} \mathrm{H}_{50} \mathrm{NO}_{22}{ }^{+}\right)$and aa fragment with $\mathrm{m} / \mathrm{z} 317.0728\left(\mathrm{C}_{16} \mathrm{H}_{13} \mathrm{O}_{7}{ }^{+}\right.$, $[\text { methylQue }+\mathrm{H}]^{+}$), were registered in the positive mode (see Figure 2 and Table 2). ${ }^{10}$ In the spectrum of KaeFA, no deprotonated molecular ion $[\mathrm{M}-\mathrm{H}]^{-}$was observed (theoretically, $\mathrm{m} / z, 866, \mathrm{C}_{39} \mathrm{H}_{48} \mathrm{NO}_{21}^{-}$), but a stable and abundant ion with $\mathrm{m} / \mathrm{z}, 901.2642$, corresponding to $[\mathrm{M}+\mathrm{Cl}]^{-}\left(\mathrm{C}_{39} \mathrm{H}_{48} \mathrm{NO}_{21} \mathrm{Cl}^{-}\right)$was found (Table 2). In the $\mathrm{MS}^{2}$ spectrum of this adduct the most abundant was the $[\mathrm{M}-\mathrm{H}]^{-}$ion $(\mathrm{m} / \mathrm{z}, 866.2718$, $\mathrm{C}_{39} \mathrm{H}_{48} \mathrm{NO}_{21}{ }^{-}$). The aglycone - a deprotonated methylkaempferol [methylKae-H] ' with $m / z 299.4627\left(\mathrm{C}_{16} \mathrm{H}_{11} \mathrm{O}_{6}{ }^{-}\right.$, also formed after cleavage of the hydroxypiperidine-2-one moiety) was registered as well. ${ }^{24}$ A precursor ion $[\mathrm{M}+\mathrm{H}]^{+}\left(\mathrm{m} / \mathrm{z}, 868.2857, \mathrm{C}_{39} \mathrm{H}_{50} \mathrm{NO}_{21}{ }^{+}\right)$was observed in positive ionization mode. Its fragmentation led to the formation of [methylKae+H] ${ }^{+}\left(\mathrm{m} / \mathrm{z}, 301.0711, \mathrm{C}_{16} \mathrm{H}_{13} \mathrm{O}_{6}^{+}\right)$as shown in Figure 2 and Table 2). ${ }^{24} \mathrm{~A}$ deprotonated molecular ion $(\mathrm{m} / z$ 753.1893, $\mathrm{C}_{33} \mathrm{H}_{37} \mathrm{O}_{20}{ }^{-}$) was observed in the spectrum of QueHMG and after cleavage of the 3-hydroxy-3-methylglutaric residue (HMG), an ion corresponding to deprotonated rutin $\left(\mathrm{m} / z, 609.1462, \mathrm{C}_{27} \mathrm{H}_{29} \mathrm{O}_{16}{ }^{-}\right)$, a fragment ion with $\left.m / z 301.0347\left(\mathrm{C}_{15} \mathrm{H}_{9} \mathrm{O}_{7}^{-}\right)[\mathrm{Que}-\mathrm{H}]^{-}\right)$, and an ion of the type [M-(rha-gal-HMG)-H] $]^{*}\left(\mathrm{~m} / z, 300.0278, \mathrm{C}_{15} \mathrm{H}_{8} \mathrm{O}_{7}{ }^{*}\right.$, most abundant in $\left.\mathrm{MS}^{2}\right)$ were registered. ${ }^{21-23} \mathrm{~A}$ precursor ion $[\mathrm{M}+\mathrm{H}]^{+}(\mathrm{m} / z, 755.2020$, $\left.\mathrm{C}_{33} \mathrm{H}_{39} \mathrm{O}_{20}{ }^{+}\right)$and an ion with $\left.\mathrm{m} / z, 303.0494\left(\mathrm{C}_{15} \mathrm{H}_{11} \mathrm{O}_{7}^{+} \text {, [Que+H] }\right]^{+}\right)$ were observed in the positive polarity (see Figure 2 and Table 2) ${ }^{21}$ In the negative mode in the spectrum of KaeHMG an ion [M-H $]^{-}(\mathrm{m} / z$ $\left.737.1942, \mathrm{C}_{33} \mathrm{H}_{37} \mathrm{O}_{19}{ }^{-}\right)$, and an ion with $m / z 593.1515\left(\mathrm{C}_{27} \mathrm{H}_{29} \mathrm{O}_{15}{ }^{-}\right.$, after HMG cleavage) were recorded. Characteristic ions of the deprotonated aglycone $\left(\mathrm{m} / \mathrm{z}, 285.0398, \mathrm{C}_{15} \mathrm{H}_{9} \mathrm{O}_{6}{ }^{-}\right)$and [Kae-H] ${ }^{\bullet}$ with $\mathrm{m} / \mathrm{z}, 284.0327$ $\left(\mathrm{C}_{15} \mathrm{H}_{8} \mathrm{O}_{6}^{-\cdot}\right)$ were observed. ${ }^{10,22,23} \mathrm{In}$ the positive mode, a precursor ion $[\mathrm{M}+\mathrm{H}]^{+}$with $\mathrm{m} / \mathrm{z}, 739.2072\left(\mathrm{C}_{39} \mathrm{H}_{39} \mathrm{O}_{19}{ }^{+}\right)$, an ion with $\mathrm{m} / z, 595.1538$ $\left(\mathrm{C}_{27} \mathrm{H}_{31} \mathrm{O}_{15}{ }^{+} \text {, [Kae-rha-gal+H] }\right]^{+}$, after $\mathrm{HMG}$ elimination), and a fragment ion with $m / z, 287.0545\left(\mathrm{C}_{15} \mathrm{H}_{11} \mathrm{O}_{6}{ }^{+},[\mathrm{Kae}+\mathrm{H}]^{+}\right)$were observed (see Figure 2 and Table 2). ${ }^{24}$ In the spectrum of camelliaside $\mathrm{A}$ an ion [M-H] $]^{-}\left(\mathrm{m} / \mathrm{z}\right.$ 755.2035, $\left.\mathrm{C}_{33} \mathrm{H}_{39} \mathrm{O}_{20}{ }^{-}\right)$was determined and. An ion of $[\mathrm{Kae}-\mathrm{H}]^{-}, m / z 285.0399\left(\mathrm{C}_{15} \mathrm{H}_{9} \mathrm{O}_{6}{ }^{-}\right)$and $[\mathrm{Kae}-\mathrm{H}]^{\bullet}$ with $m / z, 284.0328$ $\left(\mathrm{C}_{15} \mathrm{H}_{8} \mathrm{O}_{6} \cdot{ }^{-}\right)$were detected. ${ }^{11}$ A precursor ion $[\mathrm{M}+\mathrm{H}]^{+}$with $\mathrm{m} / \mathrm{z} 757.2191$ $\left(\mathrm{C}_{33} \mathrm{H}_{41} \mathrm{O}_{20}{ }^{+}\right)$was observed in positive polarity, which gave a fragment ion for $[\mathrm{Kae}+\mathrm{H}]^{+}$with $\mathrm{m} / z$ 287.0551, $\mathrm{C}_{15} \mathrm{H}_{11} \mathrm{O}_{6}{ }^{+}$(see Figure 2 and Table 2). ${ }^{10}$ In the spectrum of alcesefoliside an ion $[\mathrm{M}-\mathrm{H}]^{-}$was identified $\left(\mathrm{m} / z, 755.2045, \mathrm{C}_{33} \mathrm{H}_{39} \mathrm{O}_{20}{ }^{-}\right){ }^{10}$ The ions [Que-H] ${ }^{*}$ with $\mathrm{m} / z 300.0279$ $\left(\mathrm{C}_{15} \mathrm{H}_{8} \mathrm{O}_{7}^{-*}\right)$ and [Que-H] $]^{-}$with $\mathrm{m} / z, 301.0328\left(\mathrm{C}_{15} \mathrm{H}_{9} \mathrm{O}_{7}^{-}\right)$distinguished the compound from camelliaside $\mathrm{A}$, which had similar retention time. A precursor ion $[\mathrm{M}+\mathrm{H}]^{+}\left(\mathrm{m} / z\right.$ 757.2191, $\left.\mathrm{C}_{33} \mathrm{H}_{41} \mathrm{O}_{20}{ }^{+}\right)$was observed, as well as in $\mathrm{MS}^{2}$ the aglycone with $m / z, 303.0499\left(\mathrm{C}_{15} \mathrm{H}_{11} \mathrm{O}_{7}^{+} \text {, [Que+H] }\right]^{+}$ (see Figure 2 and Table 2). ${ }^{10}$ In the negative mode in the spectrum of mauritianin an ion [M-H] ${ }^{-}$was observed $\left(\mathrm{m} / z, 739.2100, \mathrm{C}_{33} \mathrm{H}_{39} \mathrm{O}_{19}{ }^{-}\right)$and in the $\mathrm{MS}^{2}$ ions [Kae-H] ${ }^{*}$ with $m / z 284.0329\left(\mathrm{C}_{15} \mathrm{H}_{8} \mathrm{O}_{6}{ }^{-*}\right)$ and [Kae-H] ${ }^{-}$ with $m / z, 285.0393\left(\mathrm{C}_{15} \mathrm{H}_{9} \mathrm{O}_{6}{ }^{-}\right)$were recorded. ${ }^{22-24}$ In the positive mode a precursor ion $[\mathrm{M}+\mathrm{H}]^{+}\left(\mathrm{m} / z 741.2245, \mathrm{C}_{33} \mathrm{H}_{41} \mathrm{O}_{19}{ }^{+}\right)$, and in the $\mathrm{MS}^{2}$ an ion with $\mathrm{m} / z 287.0549\left(\mathrm{C}_{15} \mathrm{H}_{11} \mathrm{O}_{6}^{+}\right)$, corresponding to $[\mathrm{Kae}+\mathrm{H}]^{+}$were found (see Figure 2 and Table 2). ${ }^{24}$

In the negative ionization mode, $17(R), 20(R)-3 \beta, 6 \alpha, 16 \beta$ trihydroxycycloartanyl-23-carboxylic acid 16 -lactone $3-O-\beta-\mathrm{D}-$ glucopyranoside (ECAS) forms a formate adduct [M-H+HCOOH] ${ }^{-}$with 
Table 2. Standard substances and analytical parameters used to identify secondary metabolites in the samples

\begin{tabular}{|c|c|c|c|c|c|}
\hline Standard substance (abbreviation) & $\mathrm{Rt} \pm \mathrm{SD}, \min$ & $\begin{array}{c}\text { Exact mass; } \\
\text { molecular formula }\end{array}$ & $\begin{array}{l}\text { ESI }(+) \text { Precursor ion; } \mathrm{MS}^{2} \\
\text { (relative abundance in } \%)^{*}\end{array}$ & $\begin{array}{l}\text { ESI (-) Precursor ion; } \text { MS }^{2} \\
\text { (relative abundance in \%)* }\end{array}$ & $\begin{array}{c}\mathrm{LOD} \pm \mathrm{SD} \\
\mathrm{ng} / \mathrm{mL}\end{array}$ \\
\hline $\begin{array}{l}N \text {-(8-methylquercetin-3-O-[ } \alpha-\mathrm{L}- \\
\text { rhamnopyranosyl- }(1 \rightarrow 2)-[\alpha-\mathrm{L}- \\
\text { rhamnopyranosyl- }(1 \rightarrow 6)]-\beta \text {-D- } \\
\text { galactopyranosyl])-3-hydroxypiperidin- } \\
\text { 2-one (QueFA) }\end{array}$ & $2.47 \pm 0.015$ & $883.2695 ; \mathrm{C}_{39} \mathrm{H}_{49} \mathrm{NO}_{22}$ & $\begin{array}{c}\text { 884.2809 } \mathrm{C}_{39} \mathrm{H}_{50} \mathrm{NO}_{22}^{+} \\
771.2345 \mathrm{C}_{34} \mathrm{H}_{43} \mathrm{O}_{20}^{+}(28) \\
625.1763 \mathrm{C}_{28} \mathrm{H}_{33} \mathrm{O}_{16}^{+}(3) \\
479.1189 \mathrm{C}_{22} \mathrm{H}_{23} \mathrm{O}_{12}^{+}(12) \\
317.0728 \mathrm{C}_{16} \mathrm{H}_{13} \mathrm{O}_{7}^{+}(100)\end{array}$ & $\begin{array}{c}\text { 882.2692 } \mathrm{C}_{39} \mathrm{H}_{48} \mathrm{NO}_{22}^{-} \\
769.2191 \mathrm{C}_{34} \mathrm{H}_{41} \mathrm{O}_{20}^{-}(21) \\
623.1612 \mathrm{C}_{28} \mathrm{H}_{31} \mathrm{O}_{16}^{-}(8) \\
477.1033 \mathrm{C}_{22} \mathrm{H}_{21} \mathrm{O}_{12}^{-}(10) \\
315.0505 \mathrm{C}_{16} \mathrm{H}_{11} \mathrm{O}_{7}^{-}(100)\end{array}$ & $0.18 \pm 0.01$ \\
\hline $\begin{array}{l}N \text {-(8-methylkaempferol-3-O- }[\alpha- \\
\mathrm{L} \text {-rhamnopyranosyl- }(1 \rightarrow 2)-[\alpha-\mathrm{L}- \\
\text { rhamnopyranosyl- }(1 \rightarrow 6)]-\beta \text {-D- } \\
\text { galactopyranosyl])-3-hydroxypiperidin- } \\
\text { 2-one (KaeFA) }\end{array}$ & $3.00 \pm 0.010$ & 867.2747; $\mathrm{C}_{39} \mathrm{H}_{49} \mathrm{NO}_{21}$ & $\begin{array}{c}\text { 868.2857 } \mathrm{C}_{39} \mathrm{H}_{50} \mathrm{NO}_{21}^{+} \\
755.2399 \mathrm{C}_{34} \mathrm{H}_{43} \mathrm{O}_{19}{ }^{+}(11) \\
609.1820 \mathrm{C}_{28} \mathrm{H}_{33} \mathrm{O}_{15}^{+}(6) \\
463.1075 \mathrm{C}_{22} \mathrm{H}_{23} \mathrm{O}_{11}^{+}(44) \\
301.0711 \mathrm{C}_{16} \mathrm{H}_{13} \mathrm{O}_{6}^{+}(100)\end{array}$ & 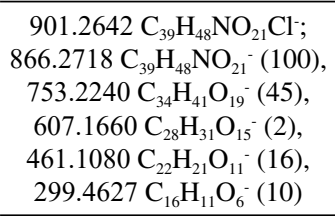 & $0.17 \pm 0.02$ \\
\hline $\begin{array}{l}\text { Quercetin-3-O- } \alpha \text {-L-rhamnopyranosyl- } \\
(1 \rightarrow 2) \text {-[6-O-(3-hydroxy-3- } \\
\text { methylglutaryl)- } \beta \text {-D-galactopyranoside } \\
\text { (QueHMG) }\end{array}$ & $5.79 \pm 0.010$ & $754.1956 ; \mathrm{C}_{33} \mathrm{H}_{38} \mathrm{O}_{20}$ & $\begin{array}{c}755.2020 \mathrm{C}_{33} \mathrm{H}_{39} \mathrm{O}_{20}+ \\
611.1593 \mathrm{C}_{27} \mathrm{H}_{31} \mathrm{O}_{16}^{+}(49) \\
465.1027 \mathrm{C}_{21} \mathrm{H}_{21} \mathrm{O}_{12}^{+}(2) \\
303.0494 \mathrm{C}_{15} \mathrm{H}_{11} \mathrm{O}_{7}^{+}(100) \\
153.0181 \mathrm{C}_{7} \mathrm{H}_{5} \mathrm{O}_{4}^{+}{ }^{+}(3)\end{array}$ & $\begin{array}{c}753.1893 \mathrm{C}_{33} \mathrm{H}_{37} \mathrm{O}_{20} \\
609.1462 \mathrm{C}_{27} \mathrm{H}_{28} \mathrm{O}_{16}-(15) \\
463.0910 \mathrm{C}_{21} \mathrm{H}_{19} \mathrm{O}_{12}^{-}(1) \\
301.0347 \mathrm{C}_{15} \mathrm{H}_{9} \mathrm{O}_{7}^{-}(22) \\
300.0277 \mathrm{C}_{15} \mathrm{H}_{8} \mathrm{O}_{7}^{-} \cdot(100) \\
151.0024 \mathrm{C}_{7} \mathrm{H}_{3} \mathrm{O}_{4}^{-}(4)\end{array}$ & $0.18 \pm 0.02$ \\
\hline $\begin{array}{l}\text { Kaempferol-3-O- } \alpha \text {-L-rhamnopyranosyl- } \\
(1 \rightarrow 2) \text {-[6-O-(3-hydroxy-3- } \\
\text { methylglutaryl)- } \beta \text {-D-galactopyranoside } \\
\text { (KaeHMG) }\end{array}$ & $6.21 \pm 0.010$ & $738.2007 ; \mathrm{C}_{33} \mathrm{H}_{38} \mathrm{O}_{19}$ & $\begin{array}{c}739.2072 \mathrm{C}_{33} \mathrm{H}_{39} \mathrm{O}_{19}^{+} \\
595.1538 \mathrm{C}_{27} \mathrm{H}_{31} \mathrm{O}_{15}^{+}(8) \\
449.1078 \mathrm{C}_{21} \mathrm{H}_{21} \mathrm{O}_{11}^{+}(1) \\
287.0545 \mathrm{C}_{15} \mathrm{H}_{11} \mathrm{O}_{6}^{+}(100) \\
153.0180 \mathrm{C}_{7} \mathrm{H}_{5} \mathrm{O}_{4}^{+}(6)\end{array}$ & $\begin{array}{c}737.1942 \mathrm{C}_{33} \mathrm{H}_{37} \mathrm{O}_{19}^{-} \\
593.1515 \mathrm{C}_{27} \mathrm{H}_{29} \mathrm{O}_{15}^{-}(12) \\
447.0917 \mathrm{C}_{21} \mathrm{H}_{19} \mathrm{O}_{11}^{-}(1) \\
284.0327 \mathrm{C}_{15} \mathrm{H}_{8} \mathrm{O}_{6}^{-}(100) \\
285.0398 \mathrm{C}_{15} \mathrm{H}_{9} \mathrm{O}_{6}^{-}(29) \\
151.0031 \mathrm{C}_{7} \mathrm{H}_{3} \mathrm{O}_{4}^{-}(3)\end{array}$ & $0.17 \pm 0.02$ \\
\hline $\begin{array}{l}\text { Kaempferol-3- } O \text {-[2- } O-\beta \text {-D- } \\
\text { galactopyranosyl-6- } O \text { - } \alpha \text {-L- } \\
\text { rhamnopyranosyl]- } \beta \text {-D-glucopyranoside } \\
\text { (camelliaside A, CamA) }\end{array}$ & $4.99 \pm 0.010$ & $756.2112 ; \mathrm{C}_{33} \mathrm{H}_{40} \mathrm{O}_{20}$ & $\begin{array}{c}\text { 757.2191 } \mathrm{C}_{33} \mathrm{H}_{41} \mathrm{O}_{20}^{+} \\
\text {611.1625 } \\
449.1091 \mathrm{C}_{27} \mathrm{H}_{31} \mathrm{O}_{16} \mathrm{H}_{21} \mathrm{O}_{11}^{+}(3) \\
287.0551 \mathrm{C}_{15} \mathrm{H}_{11} \mathrm{O}_{6}^{+}(100) \\
153.0184 \mathrm{C}_{7} \mathrm{H}_{5} \mathrm{O}_{4}^{+}{ }^{+}(2)\end{array}$ & $\begin{array}{c}755.2035 \mathrm{C}_{33} \mathrm{H}_{39} \mathrm{O}_{20} \\
609.1450 \mathrm{C}_{27} \mathrm{H}_{29} \mathrm{O}_{16}^{-}(4) \\
447.0919 \mathrm{C}_{21} \mathrm{H}_{19} \mathrm{O}_{11}^{-}(3) \\
284.0328 \mathrm{C}_{15} \mathrm{H}_{8} \mathrm{O}_{6}^{-*}(100) \\
285.0399 \mathrm{C}_{15} \mathrm{H}_{9} \mathrm{O}_{6}^{-}(47) \\
151.0026 \mathrm{C}_{7} \mathrm{H}_{3} \mathrm{O}_{4}^{-}(1)\end{array}$ & $0.19 \pm 0.01$ \\
\hline $\begin{array}{l}\text { Quercetin-3-O- } \alpha \text {-L-rhamnopyranosyl- } \\
(1 \rightarrow 2) \text {-[ } \alpha \text {-L-rhamnopyranosyl- }(1 \rightarrow 6)]- \\
\beta \text {-D-galactopyranoside (alcesefoliside, } \\
\text { Alce) }\end{array}$ & $4.94 \pm 0.010$ & $756.2114 ; \mathrm{C}_{33} \mathrm{H}_{40} \mathrm{O}_{20}$ & $\begin{array}{c}\text { 757.2191 } \mathrm{C}_{33} \mathrm{H}_{41} \mathrm{O}_{20}^{+} \\
611.1604 \mathrm{C}_{27} \mathrm{H}_{31} \mathrm{O}_{16}^{+}(27), \\
465.1023 \mathrm{C}_{21} \mathrm{H}_{21} \mathrm{O}_{12}^{+}(13) \\
303.0499 \mathrm{C}_{15} \mathrm{H}_{11} \mathrm{O}_{7}^{+}(100) \\
153.0179 \mathrm{C}_{7} \mathrm{H}_{5} \mathrm{O}_{4}^{+}{ }^{+}(1)\end{array}$ & $\begin{array}{c}755.2045 \mathrm{C}_{33} \mathrm{H}_{39} \mathrm{O}_{20} \\
609.1480 \mathrm{C}_{27} \mathrm{H}_{29} \mathrm{O}_{16}^{-}(2), \\
463.0880 \mathrm{C}_{21} \mathrm{H}_{19} \mathrm{O}_{12}^{-}(1) \\
300.0279 \mathrm{C}_{15} \mathrm{H}_{8} \mathrm{O}_{7}^{-*}(100), \\
301.0328 \mathrm{C}_{15} \mathrm{H}_{9} \mathrm{O}_{7}^{-}(13), \\
151.0030 \mathrm{C}_{7} \mathrm{H}_{3} \mathrm{O}_{4}^{-}(6)\end{array}$ & $0.16 \pm 0.03$ \\
\hline $\begin{array}{l}\text { Kaempferol-3- } O-\alpha \text {-L-rhamnopyranosyl- } \\
(1 \rightarrow 2) \text { - }[\alpha \text {-L-rhamnopyranosyl- }(1 \rightarrow 6)]- \\
\beta \text {-D-galactopyranoside (mauritianin, } \\
\text { Maur) }\end{array}$ & $5.37 \pm 0.020$ & $740.2164 ; \mathrm{C}_{33} \mathrm{H}_{40} \mathrm{O}_{19}$ & $\begin{array}{c}741.2245 \mathrm{C}_{33} \mathrm{H}_{41} \mathrm{O}_{19}+ \\
595.1655 \mathrm{C}_{27} \mathrm{H}_{31} \mathrm{O}_{15}{ }^{+}(30) \\
449.1073 \mathrm{C}_{21} \mathrm{H}_{21} \mathrm{O}_{11}{ }^{+}(15) \\
287.0549 \mathrm{C}_{15} \mathrm{H}_{11} \mathrm{O}_{6}{ }^{+}(100) \\
153.0182 \mathrm{C}_{7} \mathrm{H}_{5} \mathrm{O}_{4}^{+}{ }^{+}(2)\end{array}$ & $\begin{array}{c}739.2100 \mathrm{C}_{33} \mathrm{H}_{39} \mathrm{O}_{19} ; \\
593.1489 \mathrm{C}_{27} \mathrm{H}_{29} \mathrm{O}_{15}(2), \\
447.0929 \mathrm{C}_{21} \mathrm{H}_{19} \mathrm{O}_{11}^{-}(1), \\
284.0329 \mathrm{C}_{15} \mathrm{H}_{8} \mathrm{O}_{6}^{-*}(100), \\
285.0393 \mathrm{C}_{15} \mathrm{H}_{9} \mathrm{O}_{6}^{-}(26), \\
151.0025 \mathrm{C}_{7} \mathrm{H}_{3} \mathrm{O}_{4}^{-}(4)\end{array}$ & $0.17 \pm 0.03$ \\
\hline $\begin{array}{l}\text { Quercetin-3-O- } \alpha \text {-L-rhamnopyranosyl- } \\
(1 \rightarrow 6)-\beta \text {-D-glucopyranoside (Rutin) }\end{array}$ & $5.69 \pm 0.010$ & $610.1533 ; \mathrm{C}_{27} \mathrm{H}_{30} \mathrm{O}_{16}$ & $\begin{array}{c}611.1605 \mathrm{C}_{27} \mathrm{H}_{31} \mathrm{O}_{16}^{+} \\
465.1026 \mathrm{C}_{21} \mathrm{H}_{21} \mathrm{O}_{12}^{+}(24) \\
303.0496 \mathrm{C}_{15} \mathrm{H}_{11} \mathrm{O}_{7}^{+}(100) \\
153.0180 \mathrm{C}_{7} \mathrm{H}_{5} \mathrm{O}_{4}^{+}{ }^{+}(5)\end{array}$ & $\begin{array}{c}609.1470 \mathrm{C}_{27} \mathrm{H}_{29} \mathrm{O}_{16} \\
463.0922 \mathrm{C}_{21} \mathrm{H}_{19} \mathrm{O}_{12}^{-}(1) \\
300.0280 \mathrm{C}_{15} \mathrm{H}_{8} \mathrm{O}_{7}^{-*}(100) \\
301.0349 \mathrm{C}_{15} \mathrm{H}_{9} \mathrm{O}_{7}^{-}(48) \\
151.0028 \mathrm{C}_{7} \mathrm{H}_{3} \mathrm{O}_{4}^{-}(14)\end{array}$ & $0.14 \pm 0.01$ \\
\hline $\begin{array}{l}17(R), 20(R)-3 \beta, 6 \alpha, 16 \beta- \\
\text { trihydroxycycloartanyl-23- } \\
\text { carboxilic acid 16-lactone 3-O- } \beta \text {-D- } \\
\text { glucopyranoside (ECAS) }\end{array}$ & $10.27 \pm 0.010$ & $578.3526 ; \mathrm{C}_{32} \mathrm{H}_{50} \mathrm{O}_{9}$ & $\begin{array}{c}579.3531 \mathrm{C}_{32} \mathrm{H}_{51} \mathrm{O}_{9}^{+} \\
417.3015 \mathrm{C}_{26} \mathrm{H}_{41} \mathrm{O}_{4}^{+}(100)\end{array}$ & $\begin{array}{c}623.3438 \mathrm{C}_{33} \mathrm{H}_{51} \mathrm{O}_{11}^{-} \\
577.3381 \mathrm{C}_{32} \mathrm{H}_{49} \mathrm{O}_{9}^{-}(100) \\
415.3015 \mathrm{C}_{26} \mathrm{H}_{39} \mathrm{O}_{4}^{-}(56)\end{array}$ & $0.19 \pm 0.01$ \\
\hline
\end{tabular}

*Fragment ions in $\mathrm{MS}^{2}$ are in order of their $\mathrm{m} / \mathrm{z}$.

$m / z, 623.3438\left(\mathrm{C}_{33} \mathrm{H}_{51} \mathrm{O}_{11}\right.$, formic acid present in the eluent system), therefore Fourier transformed Selected Ion Mode (FT-SIM) was used to detect this saponin. ${ }^{11}$ In addition a FS as well as $\mathrm{MS}^{2}$ chromatogram of each sample was recorded. An ion $[\mathrm{M}-\mathrm{H}]^{-}$was observed $(\mathrm{m} / \mathrm{z}$ 577.3381 $\left.\mathrm{C}_{32} \mathrm{H}_{49} \mathrm{O}_{9}{ }^{-}\right)$, as well as a fragment ion $(\mathrm{m} / \mathrm{z}, 415.3015$, $\mathrm{C}_{26} \mathrm{H}_{39} \mathrm{O}_{4}^{-}$), corresponding to the sapogenin. The compound protonated to a small extent under positive ionization to give the $[\mathrm{M}+\mathrm{H}]^{+}$ion $\left(\mathrm{m} / z\right.$ 579.3531, $\left.\mathrm{C}_{32} \mathrm{H}_{51} \mathrm{O}_{9}{ }^{+}\right)$. A fragment ion $\mathrm{m} / z 417.3015 \mathrm{C}_{26} \mathrm{H}_{41} \mathrm{O}_{4}{ }^{+}$ was observed corresponding again to the sapogenin (see Figure 3 and Table 2).

\section{Identification of compounds in the samples}

The difference in retention times of the standards (Table 2) and the compounds in the samples was less than 0.05 min (mean value of three injections) and considered acceptable..$^{25}$ The TIC-FS chromatograms of each sample are in Supplementary. QueFA was identified in extracts from A. monspessulanus subsp. monspessulanus, collected both from Devin (Sample 7) and from Slavianka (Sample 8). This finding corroborates the presence of this flavoalkaloid in the species (Table 3). ${ }^{5}$ No other of the species examined accumulated the 
Table 3. Secondary metabolites* identified in the samples

\begin{tabular}{|c|c|c|c|c|c|c|c|c|c|c|}
\hline Sample No. & Species & QueFA & KaeFA & QueHMG & KaeHMG & CamA & Alce & Maur & Rutin & ECAS \\
\hline$\overline{1}$ & A. cicer & - & - & - & - & - & + & + & + & - \\
\hline 2 & A. cicer & - & - & - & - & - & + & + & + & - \\
\hline 3 & A. depressus & - & - & - & + & - & - & - & - & - \\
\hline 4 & A. glycyphylloides & - & + & - & - & + & + & + & - & - \\
\hline 5 & A. glycyphyllos & - & - & - & - & + & - & + & + & + \\
\hline 6 & A. glycyphyllos & - & - & - & - & + & - & + & + & + \\
\hline 7 & A. monspessulanus subsp. monspessulanus & + & + & - & - & - & + & + & + & - \\
\hline 8 & A. monspessulanus subsp. monspessulanus & + & + & - & - & - & + & + & + & - \\
\hline 9 & A. monspessulanus subsp. illyricus & - & - & + & + & - & + & + & + & - \\
\hline 10 & A. onobrychis var. chlorocarpus & - & + & - & - & + & + & + & + & + \\
\hline 11 & A. onobrychis var. chlorocarpus & - & + & - & - & + & + & + & + & + \\
\hline 12 & A. onobrychis var. chlorocarpus & - & + & - & - & + & + & + & + & + \\
\hline 13 & A. ponticus & - & - & - & - & - & & + & + & - \\
\hline
\end{tabular}

*Abbreviations are as in Table 2.

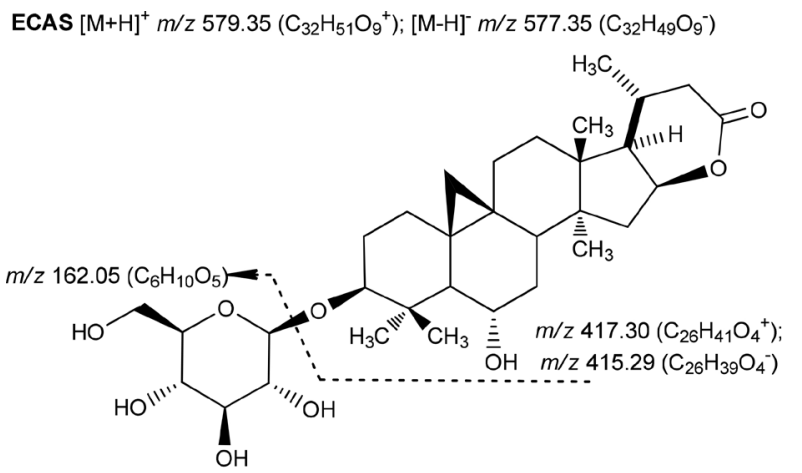

Figure 3. Fragmentation of ECAS; abbreviation is as in Table 2

12, Table 3). Analysis of the samples of A. monspessulanus (both subspecies, Samples 7, 8, 9, Table 3) confirmed the previously reported data. ${ }^{5}$ Mauritianin was identified in the aerial parts of A. glycyphylloides (Sample 4) and A. onobrychis var. chlorocarpus (Samples 10, 11, 12 of Table 3), in A. cicer (Samples 1 and 2 Table 3) and in A. ponticus (Sample 13, Table 3). The results of the analysis of both subspecies of A. monspessulanus (monspessulanus, Samples 7 and 8, and illyricus, Sample 9, Table 3) coincide with previous reports. ${ }^{13}$

The presence of the epoxycycloartane saponin in the two samples of A. glycyphyllos confirmed a previous report. ${ }^{11}$ The ECAS was identified for the first time in all extracts of A. onobrychis var. chlorocarpus (Table 3 ).

\section{CONCLUSIONS}

A novel rapid UHPLC-HRESIMS method was applied to detect rare flavoalkaloids, acylated and highly glycosylated flavonoids as well as a cycloartane saponin in samples of Bulgarian Astragalus species. These results will serve as the basis for thorough phytochemical screening of all Bulgarian representatives of this genus.

\section{ACKNOWLEDGEMENTS}

This work was supported by the Bulgarian Ministry of Education and Science under the National Program for Research "Young Scientists and Postdoctoral Students".

\section{REFERENCES}

1. Zarre, S.; Azani, N.; Prog. Biol. Sci. 2013, 3, 1.
2. Podlech, D.; Feddes Repertorium 2008, 119, 310.

3. Asyov, B.; Petrova, A.; Dimitrov, D.; Vasilev, R. Conspectus of the Bulgarian vascular flora. Distribution maps and floristic elements; Bulgarian Biodiversity Foundation: Sofia, 2012.

4. Krasteva, I.; Shkondrov, A.; Ionkova, I.; Zdraveva, P.; Phytochem. Rev. 2016, 15, 567.

5. Krasteva, I.; Bratkov, V.; Bucar, F.; Kunert, O.; Kollroser, M.; KondevaBurdina, M.; Ionkova, I.; J. Nat. Prod. 2015, 78, 2565.

6. Khadem, S.; Marles, R. J.; Molecules 2011, 17, 191.

7. Porter, E. A.; van den Bos, A. A.; Kite, G. C.; Veitch, N. C.; Simmonds, M. S. J.; Phytochemistry 2012, 81, 90.

8. Semmar, N.; Fenet, B.; Gluchoff-Fiasson, K.; Hasan, A.; Jay, M.; J. Nat. Prod. 2002, 65, 576.

9. Simeonova, R.; Bratkov, V. M.; Kondeva-Burdina, M.; Vitcheva, V.; Manov, V.; Krasteva, I.; Redox Rep. Commun. Free Radic. Res. 2015, $20,145$.

10. Andersen, O. M.; Markham, K. R. Flavonoids: chemistry, biochemistry and applications; CRC press, 2005.

11. Shkondrov, A.; Krasteva, I.; Bucar, F.; Kunert, O.; Kondeva-Burdina, M.; Ionkova, I.; Nat. Prod. Res. 2020, 34, 511.

12. Krasteva, I.; Nikolov, S.; Kaloga, M.; Mayer, G.; Zeitschrift fur Naturforsch. - Sect. B J. Chem. Sci. 2006, 61, 1166.

13. Shkondrov, A.; Krasteva, I.; Bucar, F.; Kunert, O.; Kondeva-Burdina, M.; Ionkova, I.; Phytochem. Lett. 2018, 26, 44.

14. Chaudhary, L. B.; Rana, T. S.; Anand, K. K.; Taiwania 2008, 53, 338.

15. Uekane, T. M.; Aquino Neto, F. R.; Gomes, L. N. F.; Quim. Nova 2011, $34,43$.

16. International conference on harmonization, Geneva, Switzerland, Guideline, 2005, pp. 11.

17. Bratkov, V.; Shkondrov, A.; Zdraveva, P.; Krasteva, I.; Pharmacogn. Rev. 2016, 10, 11.

18. Maamria, L.; Haba, H.; Lavaud, C.; Harakat, D.; Benkhaled, M.; J. Serbian Chem. Soc. 2015, 80, 137.

19. Benbassat, N.; Nikolov, S.; Planta Med. 1995, 61, 100.

20. Fabre, N.; Rustan, I.; de Hoffmann, E.; Quetin-Leclercq, J.; J. Am. Soc. Mass Spectrom. 2001, 12, 707.

21. Alves, C. Q.; David, J. M.; David, J. P.; Villareal, C. F.; Soares, M. B. P.; Queiroz, L. P. de; Aguiar, R. M.; Quim. Nova 2012, 35, 1137.

22. Demarque, D. P.; Crotti, A. E. M.; Vessecchi, R.; Lopes, J. L. C.; Lopes, N. P.; Nat. Prod. Rep. 2016, 33, 432.

23. Ablajan, K.; Tuoheti, A.; Rapid Commun. Mass Spectrom. 2013, 27, 451.

24. Farias, L. da S.; Mendez, A. S. L.; Quim. Nova 2014, 37, 483.

25. Swartz, M. E.; Krull, I. S.; Analytical method development and validation; CRC Press: Boca Raton, 2018. 